https://helda.helsinki.fi

\title{
Exploring cultural acceptability of a hypothetical results-based agri-environment payment for grassland biodiversity
}

\section{Birge, Traci Lynn}

2019-04

Birge , T L \& Herzon , I 2019 , ' Exploring cultural acceptability of a hypothetical results-based agri-environment payment for grassland biodiversity ' , Journal of Rural Studies , vol. 67 , pp. 1-11 . https://doi.org/10.1016/j.jrurstud.2019.02.006

http://hdl.handle.net/10138/301126

https://doi.org/10.1016/j.jrurstud.2019.02.006

draft

Downloaded from Helda, University of Helsinki institutional repository.

This is an electronic reprint of the original article.

This reprint may differ from the original in pagination and typographic detail.

Please cite the original version. 


\title{
Exploring cultural acceptability of a hypothetical results-based agri-environment payment for grassland biodiversity
}

\author{
Traci Birge*, Irina Herzon \\ Department of Agricultural Sciences, P.O. Box 27, FI-00014, University of Helsinki, Finland
}

\section{Introduction}

Agri-environment-climate schemes (AES) form the most important policy instrument for conservation of biodiversity in the European Union, including Finland (European Environment Agency, 2004). The AES budgets regularly equal or exceed the amount of money spent on wildlife and nature conservation efforts through other routes (Batáry et al., 2015). Despite this large expenditure, farmland biodiversity continues to decline in all EU member states, and AES are too limited in extent to reverse the larger-scale impacts of other CAP instruments (Pe'er et al., 2017). Other shortcomings of the current system range from insufficiently clear policy aims and associated problems with monitoring to lack of flexibility of implementation under varied site conditions to poor cultural sustainability (Burton and Paragahawewa, 2011; European Court of Auditors, 2011; Poláková et al., 2011)

The current system is based on prescribed actions to be carried out and is heavily top down. Farmers are mainly obligated to carry out actions, sometimes according to specific dates, for payment. Prescribed management actions may not favour, or even identify, optimal management for meeting conservation targets on a particular site or empower managers to address issues or conditions for optimal management (Pullin and Knight, 2003). Additionally, the actions-based approach is criticized as lacking cultural sustainability: it has failed to instil long-term attitudinal change amongst farmers (Burton and Paragahawewa, 2011) and is claimed to 'disincentivise' farmers by introducing a highly regulatory environment that discourages innovative and site-specific approaches and instead links farmer behaviour more to monetary stimuli than appreciation of results of their work (Hodge, 2001; Kaljonen, 2006, 2008; Herzon and Mikk, 2007; Burton et al., 2008; Keenleyside et al., 2011). Cultural resistance to agricultural measures that are perceived to affect the identities of farmers as food pro-

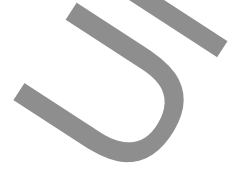

\footnotetext{
* Corresponding author.

Email address: traci.birge@helsinki.fi (T. Birge)
}

ducers have been proposed as a reason for limited success of current AES (Burgess et al., 2000; Burton, 2004). Farmers are also subject to a verification process over which they have little say and which they often perceive as threatening for such reasons as being overly rigid, complex, and subject to interpretation by individual inspectors or local bureaus (Wilson and Hart, 2001; Helenius and Seppänen, 2004; Birge and Herzon, 2014). Thus, AES needs to become more supportive of farmers and less threatening by reducing bureaucracy and increasing the advisory nature of the system. Steps that need to be taken to improve AES efficiency include becoming more results-oriented, improving targeting and tailoring of measures, articulating objectives more clearly, and creating clearer indicators for measuring success (European Network for Rural Development and the European Commission, 2010; European Court of Auditors, 2011). Efficient AES policy will require both effective AES and sufficient budget to carry them out. On environmental efficiency, a recent external fitness check of the EU's Common Agricultural Policy found negative relation between the effectiveness of the different CAP instruments and their budget (Pe'er et al., 2017).

The results-based approach refers to payment schemes that reward farmers or land managers for environmental results achieved rather than actions undertaken and was recommended by the European Court of Auditors (2011 pp. 49) as a potential way forward to overcome obstacles of the existing actions-based approach. The approach is mainly oriented toward maintaining existing high nature value habitats rather creating new ones (Uthes and Matzdorf, 2013). The results-based approach can be considered a type of payment for ecosystem services where biodiversity and other environmental outcomes become farm products that a landowner can choose to produce in addition to agricultural goods and services (Gerowitt et al., 2003; Klimek et al., 2008; Russi et al., 2016). The results-based approach explicitly rewards land managers for achieving biodiversity results by the management regime best suited to the site and, through this, aims to make farmers active 
and purposeful participants in management for nature values. Resultsbased approaches have been piloted or are already used in some European countries with positive result (comprehensive list in Allen et al., 2014, updated in Herzon et al., 2018; see also Matzdorf and Lorenz, 2010). Most result-based schemes are so-called 'hybrid' schemes that reward land managers for results but also place some requirements or restrictions on the land management (Herzon et al., 2018).

The body of literature on the sociological aspects of results-based approach is still relatively small, with little empirical research to date on actual ecological or social outcomes (Burton and Schwarz, 2013; Fleury et al., 2015; Russi et al., 2016). A key theme of the sociological inquiry has been the approaches' potential for 'cultural sustainability' by achieving permanent change in farmers' thinking and actions towards biodiversity and management for nature values (Burton and Schwarz, 2013; Fleury et al., 2015; Magda et al., 2015). Another major theme of the literature is farmers internalising the idea of 'biodiversity production' as an environmental good they can be paid to produce (Klimek et al., 2008; Matzdorf et al., 2008; Matzdorf and Lorenz, 2010). France's flowering meadows competition (Fleury et al., 2015; Magda, 2015) and Germany's MEKA grasslands project (Russi et al., 2016) are two of the most studied results-based schemes, and both have found that participating farmers desire social recognition and appreciation for their environmental achievements. Such social research into results-based approaches further elucidates the premise, stated for example by de Snoo et al. (2013), of farmland nature conservation as a social challenge requiring the active support of the farming community.

Uptake of new ideas is needed if practices are to change on a longterm basis. The slower pace of change on the farms and in farmer thinking compared to changes in policy is cited as a hindrance to uptake of new environmental practices and AES measures (Burton and Paragahawewa, 2011; de Snoo et al., 2013; Huttunen and Peltonen, 2016). Farmers are known to be a judgmental peer group (Burton, 2012), and changing agricultural practices to something outside the norm can have negative impacts on, for example, how farmers are viewed by their peers (Burton et al., 2008; Burton and Paragahawewa, 2011; Sutherland and Burton, 2011). Because the results-based approach requires farmers to think about and plan for outcomes rather than actions only, clear communication of the management objectives as payments preconditions and understanding and acceptance of these objectives by the payment recipients is necessary (Herzon et al., 2018).

Though the results-based approach motivates farmers to achieve conservation results for their own economic benefit (Gerowitt et al., 2003; Klimek et al., 2008), for personal satisfaction (Fleury et al., 2015) and due to the farmers' intrinsic values such as ethics (Russi et al., 2016), it is not clear whether these or other potential benefits (such as collective learning process, see Magda et al., 2015) are evident to farmers without experience of the results-based approach in areas where it has yet to be introduced. Cultural acceptability of an approach is a key aspect of its cultural sustainability. Assessing cultural acceptability of the results-based approach and perceptions land managers have about it is an important prerequisite for trialling (Herzon et al., 2018).

Currently, AES in Finland do not include results-based schemes or elements. We examine the potential cultural acceptability of the results-based approach in Finland using a hypothetical bonus element (a results-based payment on top of the existing base payment) for an existing scheme called nature management grassland (NMG), which is a popular measure with a low threshold for participation. The main concepts we use in evaluating cultural acceptability are 'good farming', cultural scripts (especially as relates to good farming and tidy farms), and the visibility of nature to farmers. The specific questions we address are i) how the 'managing for nature values' approach fits with ize ecological results, for which they would be rewarded, and iii) whether the results-based approach enhances or dilutes the current 'good farmer' ideal held by the farmers.

The paper is presented as follows: Firstly, we present the theoretical concepts used and context. Secondly, we describe the nature management grassland scheme in Finland and how the hypothetical scheme we developed would work, and the methods used in the research. Thirdly, we present the results followed by discussion in light of the key concepts described earlier. We conclude with a brief summary regarding the potential for the results-based approach from the perspec tive of cultural sustainability, as well as the contribution of the findings to development of the results-based approach.

\section{Constructing views of farming}

Farming and nature conservation can be seen as social processes in which people and things are inseparable from the social processes in which they are embedded (Ahnström, 2009). In this view, social relations of farming exist in three contexts of the farmer: physical and ecological, social, and the personal (Ahnström, 2009). Two tools that have previously been used to make sense of how farmers and agrarian societies construct their views of farming are cultural scripts and farmers' own views of what constitutes good farming or being a good farmer (Burton 2004, 2012; Silvasti, 2003b). Cultural scripts refer to learned or socially conditioned ideas of how things are and should be done and have been widely used in, for example, social psychology and gender and sexuality research, but applied in only a few cases to rural sociology (Vanclay and Enticott, 2011). Both the cultural scripts concept and construction of notions of good farming suit the view of farming and nature conservation as social processes interacting across the three contexts. Cultural scripts and views of good farming influence the behaviour of farmers (Vanclay and Enticott, 2011; Burton, 2012), which is why they should be taken into account in policy. A third construct, visibility of nature to farmers, is not an established social concept of itself but may be found in cultural scripts and views of good farming. By visibility of nature to farmers, we refer to how and what farmers recognize as nature on their farms and farm environs. We propose it as a tool here because cultural acceptability and sustainability of the results-based approach is dependent in part on a capacity for seeing and appreciating benefit to nature (Bergeå et al., 2008).

Silvasti's (2003 a \& b) cultural scripts approach incorporates the cultural, ideological and social factors at the society level with the experiences and beliefs at the personal level to identify scripts that have a strong normative character (Vanclay et al., 2007). Silvasti's use of script theory draws on Simon and Gagnon (1984) to describe scripts as 'mental maps' representing sets of rules, values, behavioural patterns, and expectations determined by society or a particular subculture (Vanclay and Enticott, 2011). Silvasti originally applied the method to understanding farming as a way of life in Finland. Silvasti (2003a, 2003b) and Vanclay et al. (2007) conclude that Finnish farmers carry many peasant farming scripts, such as continuity of the family farm, the gender script, the script of hard work, and the script of farming as a tended garden. Vanclay et al. (2007) assert that continuity - handing the farm on to the next generation - is the dominant script that affects all other scripts. Silvasti (2003b) found that Finnish farmers simultaneously see themselves as, and derive identity from, being producers and lands stewards while downplaying the environmental costs of their agriculture. With the overlap of scripts in Australia and Finland and similar concepts found in other literature, Vanclay et al. (2007) suggest that many of the scripts identified by Silvasti are probably universal to industrialized nations. Importantly for policy implementation, Silvasti (2003a, 2003b) found that attempts to override the values and practices represented by the cultural scripts tend to fail (Vanclay and 
'Good farmer' or 'good farming' is used in different ways in the literature to gain an actor perspective for understanding construction of farmer identity, views and motivations for behaviour. It has been widely used in understanding farmers' development to more environmentally sustainable agricultural practices (Silvasti, 2003b; Burton et al., 2008; Huttunen and Peltonen, 2016). Good farming ideals shift as a result of changing policy, economic, societal, and family contexts and values (Sutherland and Darnhofer, 2012; Huttunen and Peltonen, 2016). Vanclay and others suggest 'good farm management' is the second dominant script and, as with the cultural script of continuity, informs all other cultural scripts (Vanclay et al., 2007). In this view, the script of good farm management underpins the very subculture of farming life and is imbued with meaning about norms, appropriate social behaviour, values, and even the preferences for dress, music and politics (Vanclay et al., 2007).

Burton's extensive development of 'good farmer' is rooted in Bourdieu's (1986) framework of different types of capital, specifically social and cultural capital (Burton and Paragahawewa, 2011). In this view, social relationships, dispositions, knowledge, skills and possession of cultural significant objects are considered types of non-economic but significant capital alongside economic capital. Central to this conceptualisation is the idea of trade-offs and transferability between the different types of capital via symbolic capital of prestige, status and reputation. Good reputation of a farm or farmer can aid in securing cooperation of other farmers, and farmers who deviate from accepted norms are likely to develop bad reputations (Burton, 2012).

The cultural script of continuity is evident in the concepts of habitus and in 'living one's field'. Habitus, the habits, skills and dispositions formed by our life experiences, is described by Bourdieu (1984) as created by 'an interplay' of freewill and structures over time. It is often used in association with good farming research (e.g. Burton, 2008, 2012; Sutherland and Darnhofer, 2012; Riley, 2016; Saunders, 2016) to describe how the social-cultural and structural context of farming creates identity and a sense of place that forms a body (habitus) in which the farmer operates. Similarly, Kaljonen (2006) described 'living one's field', where farmers' knowledge is rooted in the history of their farms and has developed in a particular place as they practice their profession and live their lives. Ahnström et al. (2008) found farmer interest in nature conservation on farms to be highly tied to continuity of the family farm.

Both as a cultural script and as an understanding of trade-offs across forms of capital, 'good farmer' is useful for understanding farmer worldviews. Burton (2004) found that farmers explicitly judge their peers as 'good' or 'bad' farmers on two criteria: physical appearance of their crop/animals and the yield. Thus, the intersection of production and landscape is central both to conservation on farmlands and to notions of good farming.

In the Bourdieusian view, ecological results have to become part of the farming culture and of farmers' 'symbolic capital' (Burton and Paragahawewa, 2011) that conveys information on reputation or social status to peers. Traditionally, such symbolic capital is embodied in production goals and in having a visibly 'tidy' farm - known attributes of a 'good farming' ideal (Silvasti, 2003; Burton, 2004, 2012; Riley, 2014, 2016). 'Tidy landscape' has strong productivist meaning in the farming communities (Burton, 2012) and again relates to both good farming and cultural scripts, with uniformity conveying work ethic and skill (Silvasti, 2003; Burton 2004, 2012; Schneider et al., 2010; Riley, 2014; de Krom, 2017). The ordered landscape also represents the farmer's ability to control nature (Little, 2002; Vanclay et al., 2007; Silvasti, 2003b). In Silvasti's research, Finnish farmers emphasised how the farm looks when asked to describe a good farmer (Vanclay et al., 2007). Research into aesthetic preference for landscapes shows that farmers rate industrial agricultural landscapes - the least preferred by ferred by all other groups - lowest (Burton, 2012). Further, farmers and conservationists have been previously shown to hold different views of good nature management (Burgess et al., 2000): farmers also included such activities as trimming ditches and verges, weed control, and other elements of the 'tidy farm' narrative as non-production nature activities, although many of these activities are contrary to biodiversity conservation.

\section{Case study and methodological approach \\ 3.1. Hypothetical scheme for nature management grassland}

The aim of our research is to examine the potential cultural acceptability of the results-based approach in Finland. We developed a hypothetical results-based scheme using nature management grassland (NMG) as an example (Birge et al., 2017). NMG is one of several AES options for non-commodity arable fields in Finland. Other options targeting biodiversity include sown meadow field, landscape field, game field and field established for cranes, geese and swans (the latter type is restricted regionally). Other arable areas relevant for biodiversity are buffer zones, catch crops and green manure field. We chose the NMG scheme as a testing ground because of participant heterogeneity and potential for improved management actions to positively impact biodiversity value. Specifically, NMG is a popular scheme in Finland with presence on $46 \%$ of Finnish farms (Natural Resources Institute Finland, pers. comm.). It currently has a minimal management obligation and high variability in biodiversity value as measured in plant species richness which, according to Toivonen et al. (2013) varies from as few as five to over 50 species on the sampled NMG parcels.

From 2015, the year interviews were conducted for this study, the annual payment rate for NMG was $100 €$ /ha or $120 € /$ ha in target areas. The combined maximum area allowed for fallow and NMG is $25 \%$ of arable area, and permanent grassland is excluded as ineligible for these measures (MAVI, 2018). The management requirements for NMG in clude keeping the vegetated cover for at least two years, biennial mowing and proscribed agri-chemical use after establishment. Actual management ranges from occasional mowing and leaving the cut material on site to mowing for fodder or grazing the sites (Toivonen et al., 2015). NMG includes both short-term (e.g. two years) fallows, usually as a part of crop rotations, and long-term fallows on fields that farmers find difficult to take into cultivation for various reasons. The scheme does not differentiate between short-term sown and long-term (seminatural) fallow.

In our hypothetical results-based scheme, farmers would receive a basic rate for establishing the NMG, as is currently the case, but would also be free to choose management practices so that the field might be eligible for a bonus payment based on the biodiversity value of the vegetation. The owner would be able to determine the present biodiversity value by identifying indicator plant species observed in a standard procedure (self-monitoring). In our hypothetical results-based scheme, the biodiversity value is based on a list of 27 species that can be regarded as indicators for the type of field in question (from data of Toivonen et al., 2015). Of these, any combination of seven species would be the minimum to qualify for the bonus payment. To participate in the results-based portion of the scheme, a farmer would have to be able to identify species (or have someone else do this task) and follow a procedure for recording their presence. Thus, a risk-averse farmer can decide to apply for a bonus payment only if seven or more species occur. Farmers interested in enrolling fields that are below the indicator species threshold can learn about management through advisory materials, experimenting with practices to try to increase the num ber of species, and sowing the species. The bonus element would be subject to normal AES spot inspections (Birge et al., 2017) based on the 
mote the indicator species but did not achieve the anticipated results, only the bonus payment would be withheld.

\subsection{Farmer interviews}

We conducted 20 semi-structured interviews with farmers with NMG contracts. We conducted the interviews in 2015 in Uusimaa Province. Uusimaa is an important agricultural region of more than 3000 farms, the majority of which specialise in cereal production (1804 cereal farms, Natural Resources Institute Finland, 2016). We selected farmers from a sampling frame of 92 Uusimaa farms with NMG provided by the Information Centre of the Ministry of Agriculture and Forestry. We sent invitations describing the research to 47 farmers from the sample with multiple NMG sites. Eight farmers contacted us and we included them in the study. We then telephoned a selection of farmers from the list to request their participation. We aimed for variety among the participants and actively sought to include women, organic farms and farms with livestock in our sample. Our telephone calls resulted in another 12 interviews, while 12 farmers either declined outright mainly due to time constraints or were unable to commit to an interview until after the growing season. Six farmers did not answer the telephone calls or call back. This selection process resulted in a total of 20 farmer interviews. All but one of the interviews took place on the farms in person by the authors.

The interviewees were on average $45-50$ years old, and all but two had cereals as primary production type (Table 1). All farmers own at least a portion of the arable land they farm, and most also have rented fields. All but one (Farmer 8 - retired) are primary decision makers of the farms. The farms included present a range of farming contexts in Uusimaa, including full and part-time farmers, farms of different sizes, organic and conventional production and both highly simplified and more complex farming systems.

In most cases, both authors were present at the interviews. We structured the interviews around, firstly, discussion at the farmhouse table about the hypothetical scheme and, secondly, walks in the fields suggested by the farmers as potentially suitable sites for the bonus scheme. This structure allowed us to ensure that the approach and hypothetical scheme were understood well and placed into the context of the farmer's own farming situation. In the field, we were able to establish farmers' capacity to identify suitable sites themselves and observe their reactions to the presence or absence of biodiversity result in the form of the indicator species. We conducted interviews in Finnish for, on average, $1 \mathrm{~h}$, excluding field visits. Other family members also participated and provided input for at least part of the interview in seven cases.

At the farmhouse table, interviews focused on presentation and discussion of the approach and practicalities of the hypothetical bonus scheme, exploration of the intersection of social and cultural capital elements with uptake of the bonus scheme, and notions of good farming and the place of NMG within those conceptualisations. Early on, we introduced the key features of the hypothetical results-based scheme to the farmers, including the result-based concept and that there would be no management requirements (such as mowing) but that agri-chemical applications would be proscribed. We introduced the indicator species and specifically mentioned that the list includes such beneficial species as nectar plants and excludes any agronomically problematic species (i.e. noxious weeds). We engaged farmers in whether they would be interested in the scheme and whether they have the capacity to carry out the self-monitoring component and knowledge of best practices for producing the target biodiversity result (see interview guide in Birge et al., 2017 Appendix C). Discussions continued in the field in 10 cases, where we walked together with the farmers and searched for the indicator plant species, using an example of extension materials
Table 1

The farmers' profiles, production and information of nature management grassland schemes on their holdings (the area is based on official figures from 2014).

\begin{tabular}{|c|c|c|c|c|}
\hline ID & $\begin{array}{l}\text { Age } \\
\text { group }\end{array}$ & $\begin{array}{l}\text { Farming status and } \\
\text { primary production } \\
\text { type }\end{array}$ & $\begin{array}{l}\text { NMG in hectares, } \\
\text { number of parcels } \\
\text { in }()\end{array}$ & $\begin{array}{l}\text { Total arable } \\
\text { land (owned \& } \\
\text { rented) }\end{array}$ \\
\hline 1 & $35+$ & $\begin{array}{l}\text { Full-time, cereals, } \\
\text { conventional }\end{array}$ & & 60 \\
\hline 2 & $50+$ & $\begin{array}{l}\text { Part-time, cereals, } \\
\text { conventional }\end{array}$ & (5) & 35.5 \\
\hline 3 & $35+$ & $\begin{array}{l}\text { Full-time, cereals, } \\
\text { conventional }\end{array}$ & & 183 \\
\hline 4 & $45+$ & $\begin{array}{l}\text { Full-time, cereals, } \\
\text { conventional }\end{array}$ & & 135 \\
\hline 5 & $65+$ & $\begin{array}{l}\text { Full-time, cereals, } \\
\text { conventional }^{\mathrm{a}}\end{array}$ & $15.04(7)$ & 115 \\
\hline 6 & $60+$ & $\begin{array}{l}\text { Full-time, cereals, } \\
\text { conventional }^{\mathrm{b}}\end{array}$ & $13.92(8)$ & 25 \\
\hline 7 & $60+$ & $\begin{array}{l}\text { Full-time, specialty } \\
\text { crops, conventional }\end{array}$ & $12.38(6)$ & 53 \\
\hline 8 & $60+$ & $\begin{array}{l}\text { Full-time, cereals, } \\
\text { conventional }^{c}\end{array}$ & $4.35(9)$ & 212.5 \\
\hline 9 & $\begin{array}{l}60+ \\
\text { (father } \\
35+ \\
\text { (son) }\end{array}$ & $\begin{array}{l}\text { ull-time, cereals, } \\
\text { zonventional }\end{array}$ & $8.99(4)$ & 20.5 \\
\hline 10 & & Full-time, cereals, & $11.18(9)$ & 353 \\
\hline 11 & & $\begin{array}{l}\text { Full-time, cereals, } \\
\text { conventional }\end{array}$ & $18.83(20)$ & 250 \\
\hline & & Full-time, cereals, & $51.10(20)$ & 259 \\
\hline & & $\begin{array}{l}\text { Full-time, cereals, } \\
\text { conventional }\end{array}$ & 37.41 (18) & 150 \\
\hline & & $\begin{array}{l}\text { Full-time, cereals, } \\
\text { organic }\end{array}$ & $8.14(3)$ & 108 \\
\hline & $45+$ & $\begin{array}{l}\text { Full-time, cereals, } \\
\text { conventional }\end{array}$ & $11.28(6)$ & 86 \\
\hline 16 & $55+$ & $\begin{array}{l}\text { Full-time, dairy, } \\
\text { organic }\end{array}$ & $3.38(6)$ & 150 \\
\hline 17 & $55+$ & $\begin{array}{l}\text { Full-time, cereals, } \\
\text { conventional }\end{array}$ & $2.77(5)$ & 85 \\
\hline 18 & $35+$ & $\begin{array}{l}\text { Full-time, cereals, } \\
\text { conventional }\end{array}$ & $18.61(7)$ & 260 \\
\hline 19 & $45+$ & $\begin{array}{l}\text { Full-time, cereals, } \\
\text { conventional }\end{array}$ & $64.52(7)$ & 150 \\
\hline 20 & $35+$ & $\begin{array}{l}\text { Part-time, cereals, } \\
\text { conventional }\end{array}$ & $56.89(9)$ & 100 \\
\hline
\end{tabular}

${ }^{\text {a }}$ Retired from non-farming career, landowner and decision-maker, but daily operations managed by a farm manager.

b Officially retired, still farming because wife is not yet entitled to pension.

c Retired, still active on the farm.

ent management options for propagation of target species and for controlling species viewed by the farmers as problematic, such as thistle (Cirsium spp.). Further, we discussed implementation and verification options, for which some farmers offered their own solutions. In some cases and at the farmers' request, we visited multiple NMGs, as well as a few buffer zones, suggested by the farmers as likely places to find the indicator species. Birge et al. (2017) shows that, in the majority of cases, farmers identified at least one NMG site on their farm that would meet the bonus criteria already by having at least $>7$ indicator species. In seven cases, we visited NMG suggested by farmers without them being present. Immediately after the interviews and field visits, the two interviewers conducted a reflection session on the visit, which we also recorded.

\subsection{Analysis}

The data we use for this paper are: 1) transcriptions of the farmer interviews; 2) recordings of our initial impressions of the interviews 
ence and key findings immediately post-interview. We used software ATLAS.ti (Atlas.ti software 1999) to facilitate the analysis.

We used a thematic qualitative approach to analysis, where we allowed the iterative process to open the data and guide development of the codes and themes used (Gibson and Brown, 2009; Ryan and Bernard, 2003). Themes and sub-themes developed from an overlapping data collection and analysis process. Leaning on the discourse analysis observation by Paulus and Lester (2016) that 'language is always doing something' and following Ryan and Bernard's (2003) guidance for thematic analysis, we probed the data for repetitions, indigenous typologies, transitions, similarities and differences, linguistic connectors, missing data and theory-related material.

Initial categorisation of the data began during the course of the interviews, as we recorded notes about each interview immediately postinterview and wrote summaries of each interview. Recorded notes captured the researchers' initial impressions and discussion on emergent themes. Summaries described the farm/farmer, interview context, and main message. This aided in recalling specifics of the interview scenarios and developing an overall picture of the data during collection stages.

In exploring farmers' comprehension of the proposed results-based scheme and the results-based approach as a concept we focused on how the discussion developed (attitude, perceptions, language) as the farmers, at the farmhouse table and in the field, considered this different way of approaching an AES scheme. We used their questions and comments to assess comprehension of the scheme's biodiversity aim. In exploring the proposed results-based scheme's conformity to current conceptions of good farming (and associated cultural scripts) and the capacity of the farmers to operationalize ecological results within the framework of the results-based approach, we examine three themes that emerged from the coding process: farmers' ideals for and NMG's relationship to good farming; the roles of peer or societal pressure and personal preference in managing for nature; and the visibility of nature, including in the NMGs, to the farmers. Following assertions that both practices (Huttunen and Peltomaa, 2016), as well as values and attitudes (Maybery et al., 2005) are important for understanding farmers' participation in AES and in shaping good farming ideals, we classify the farmers according to the integration of nature values into their thinking and practice on the farm.

\section{Results}

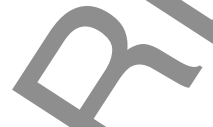

\subsection{Farmers' reasons for entering nature management grassland contracts} in current and in hypothetical results-based scheme

Decision-making for having NMG contracts is based on individual farming strategies and navigation of Common Agricultural Policy and AES rules governing how much land can or must be allocated to different uses. Further, farmers pointed out that restrictions that limit field production activities, e.g. agri-chemical restrictions in water catchment areas, influence decision-making about putting land into NMG contracts.

The main drivers for choosing the NMG contract specifically were (Table A1): convenience or best subsidy format for specific parcels (18), agronomic reasons (5) and, as secondary drivers, biodiversity or nature values (5). Farmers described NMG mainly as a marginal farm element: 'mostly small parcels, surrounded by forest and difficult to farm with modern machinery ... their production value isn't such that they can be farmed productively nowadays' (Farmer 18). Agronomic reasons refers to the short-term NMG frequently used in crop rotation: 'Well probably change the location of the NMGs after this year, it depends on the percentages, if we have too much we don't get the subsidy' (Farmer 9).

For the hypothetical scheme, farmers were most attracted to being most concerned about the procedure for verification of result and about fields spreading weeds or looking unkempt. The former is a practical issue, while the latter relates to farmers' deeply held views on how farms should look and what constitutes good farming.

\subsection{Visibility of nature to farmers}

Visibility of nature varied among the farmers from high levels of observations and knowledge of different species to almost no mention of nature. The majority of farmers interviewed said hunting occurs on their farms, and hunting and field work were the two activities in which nature was most visible. Farmers described their observations of farmland birds and game species, 'usually during the work' (Farmer 7) and ways of promoting game or protecting farmland birds during cultivation. Hunting was presented as a socially acceptable way of being in and observing nature: 'Our hunting group doesn't have a need to shoot. Rather, it's more game management and enjoying the observation and following how the population grows. We talk among ourselves about where someone saw a doe and fawn or a fine stag or that sort of thing ... often we don't fulfil our quota-it's not the main thing' (Farmer 8).

Nature associated with the fields and with hunting is also visible as part of the inter-generational knowledge and a link to the farm and family history:

Son: Yes, this spring was challenging. I hadn't even noticed before that there's northern lapwing nesting in our field, with four very tiny chicks. At times $I$ had to stop the tractor because they tumbled over. The crows and jackdaws tried to eat them.

Interviewer. So you make a lot of observations here?

Son: Yes. In those days when Pappa (grandfather) was still alive, the curlew's nest was always marked.

Father: Now the curlews have come back again, in our field, too. One was over there. Hadn't nested, yet.

Son: And the starlings have returned.

Interviewer: Do you have cattle, animals?

Son: Well, we don't. But for some reason they've come back. But the swallows have disappeared.

(Farmers 9, father and son)

The conversation here contains elements of Bourdieu's habitus concept, and the visibility of nature through intergenerational connections on the family farm also reflects Kaljonen's (2006), observation of 'living one's field'. These examples illustrate the role of nature observation in sense of place.

We used farmers' activities, expressed values, and thought processes for taking nature into consideration in farm planning to classify respondents according to the integration of nature values or strategies for managing the farm. We identified four classes, or levels, of integration of nature values or strategies in the farming (Table 2).

Farmers with nature values integrated into their farming had observations and activities unrelated to hunting and farming. However, those with little nature values thinking in their farming also had sparse nature observations, with one farmer relating only structural changes on the farm: 'Probably the landscape has also changed when the farms

Table 2

Classification of farmers according to the extent to which they take nature into considera tion in their farm planning and activities.

\begin{tabular}{ll}
\hline Integration of nature values or strategies in farming & $\begin{array}{l}\text { Number of } \\
\text { farmers }\end{array}$ \\
\hline $\begin{array}{l}\text { Nature values highly central } \\
\text { Nature values well integrated, with clear multifunctional thinking, } \\
\quad \text { strategies and knowledge }\end{array}$ & 3 \\
$\begin{array}{l}\text { Positive toward nature values but little visible role outside of } \\
\text { fallows or game management }\end{array}$ & 4
\end{tabular}


have grown and field production has changed. Open ditches have been replaced by sub-surface drainage and so forth, but I don't see anything negative in that.' (Farmer 18)

In our study, farmers frequently required prompting to relate nonproduction nature activities they engage in. Small or 'regular' management for nature (e.g. putting up bird nesting boxes or managing a corner of the forest to shelter game birds) done out of own interest and outside of formal structures (e.g. subsidies) or environmental groups was common.

\subsection{Good farmers, tidy farms and learning to see nature}

Farmers' views of good farming can be summarized as what happens and shows in the field. The strong evidence for the 'tidy farm' ideal was also tempered by tolerance for some semi-natural quality of the NMG: 'Some [NMGs] are a mess. They should be managed looking, too, in their own way. If they are mown, then that's done a bit later, but it's different looking than something that's just been neglected' (Farmer 17). Controlling weeds was a clear aspect of good farming conceptualisations for the farmers and related directly to the NMGs. Nearly all farmers, including those who were very positive about the proposed resultsbased scheme, brought up a concern for weeds on NMG. The farmers confirmed that they do not view the indicator species as weeds.

Aesthetic acceptance was based on whether NMG was viewed as having meadow qualities (favourable; such as Farmers 5, 8 and 13) or weedy field qualities (unfavourable; Farmers 4 and 18 most strongly). In the latter case, we identified greater tolerance for long-term NMG if it is separate from the main fields or away from the open arable landscape.

Discovery of indicator species in the fields, particularly when the field met or nearly-met the proposed requirement of seven indicator species, engendered pride, with the greatest enthusiasm in cases where we found relatively rare species, such as brown moor (Trifolium spadiceum) or golden clover (T. aureum) or found many indicator species in a very short period of time.

Nature associated with NMG was not visible to most farmers, even if most farmers did have a good idea of which NMG parcels on their farms would be suitable for the bonus scheme (Birge et al., 2017). In contrast to NMG, another actions-based AES called game field was brought up by several farmers as a dynamic management model with visible benefits for biodiversity. The farmers in our study described enjoyment they get from planning the game field and following the results. The clear contract aim (feeding game species), shorter contract (1 growing season + winter) and higher compensation (300€/ha) may all have a role in the farmers paying more attention to nature in the game fields compared to NMG.

In the field, most farmers could envision the specific results for NMG and a quality of the NMGs that they had not considered previously. For example, a sceptical farmer (4) became much more positive toward the scheme upon visiting one of his NMGs that was rich in indicator species (it also was tucked away from the main fields and unlikely to be taken into production). The farmer was satisfied about the indicator species found and began describing other positive qualities of the parcel, such as a refuge for birds and game. Similarly, Farmer 5, who described NMG management on his farm as 'the absolute minimum' - meaning the only management is mowing without removing the cut material - and the outcome 'sad', declared that he would change mowing practices to promote seeding of the target species. Some farmers also started to innovate, coming up with ideas for verification and indicator species-oriented management practices. Learning to see the NMG with an eye to 'producing' biodiversity proved positive and fits farmers' conceptualisation of good farming as utilising the land fully.

We asked farmers directly what 'good farmer' means to them and lenged the question of whether NMG fits into their good farming concept (Why wouldn't it/why not?), which we interpret as confirmation that currently farmers see the farm as having space for non-production elements. Differences between the farms' productive areas and NMG were also described as acceptable in good farming conceptualisations: 'Good farming is that fields look one way and the NMG looks another' (Farmer 9) and 'If you have production you do it well and if you have NMG you do that well' (Farmer 17).

Nearly all farmers explicitly pointed out that the primary role of agriculture is food production. Overall, farmers emphasised practicality: 'It fits exactly for those lower quality cereals/feed production parcels those can be put into NMG, not these [good] cereal fields' (Farmer 12).

The question about good farming came in the second half of the interview and was preceded by discussion about nature values, which likely explains the frequency of references to nature in the farmers' thinking about 'good farmer' (Table 3). A few themes stand out: only three farmers mentioned following the rules or effective use of subsi dies are elements of a good farmer, while twice that number mentioned taking farming seriously, including not just for subsidies. Professional skills, good agronomic practices, and investing back into the farm also far outweighed maximising yield (mentioned by only two). However, it is clear that almost all farmers are producers and work to have good yields, and several farmers mentioned they aim for 'good, but not maximum' harvests.

The majority of farmers viewed the results-based approach and the proposed results-based scheme favourably (Table 4), and over half knew of peers who they thought would be positive toward the scheme, with some specifically mentioning organic farmers or others they perceived as having strong nature values. An opposing view, that efficient use of land is in the best interest of nature, shows a strong productivist attitude, but was also tempered by the acknowledgement that 'most farms have an unproductive corner' (Farmer 18) where fallow is sensible. NMG and other similar fallow options in the Finnish system keep the arable land available for future agronomic production. The view that 'good farmland' should not be put into the scheme was also reflected by others and summed up by one couple with 2.5 ha NMG under their management that is too far away $(15 \mathrm{~km})$ and too low-producing to cultivate: 'Since it's been in NMG, the neighbours there have commented on how nice it looks, with all different species growing there ... but I don't know what they'd think if it were placed in the middle of a field. They would wonder if we're planning our retirement already' (Farmer 17).

\subsection{Operationalizing ecological results}

Farmers mainly grasped the biodiversity outcome meaning of the proposed results-based scheme (Table 4), but capacity to intentionally propagate the indicator species while controlling undesirable species is limited by lack of knowledge. Farmers stated the need for guidance, 'there should be some kind of information. I don't know how to promote the

Table 3

Summary of the elements included in farmers' definitions of 'good farmer', with cate gories derived from the responses.

\begin{tabular}{ll}
\hline Definitions of good farmer/farming & $\begin{array}{l}\text { Response } \\
\text { frequency }\end{array}$ \\
\hline Nature or landscape stewardship & 13 \\
Professional skills, incl. good thinking \& decision-making & 10 \\
Good agronomic practices, incl. controlling weeds, managing & 10 \\
$\quad$ nutrients & 8 \\
Production, incl. making a living \& good business skills & 6 \\
Taking farming seriously, incl. not just for subsidies & 4 \\
Improving/investing back into your farm & 3 \\
Following the rules, incl. effective use of subsidies & 3 \\
Being a good neighbour and good/active member of society & 2
\end{tabular}


Table 4

Farmers' attitudes toward the scheme and comprehension of biodiversity aims. Example quotes are taken from the interviews at the farmhouse table. Results by individual farmer are available in Table A2 and A.3 (Appendices).

\begin{tabular}{|c|c|c|}
\hline $\begin{array}{l}\text { Attitude toward } \\
\text { scheme \& concept }\end{array}$ & $\begin{array}{l}\text { Number of } \\
\text { respondents }\end{array}$ & Example of quotes \\
\hline Positive throughout & 14 & $\begin{array}{l}\text { Other schemes could have a bonus component, } \\
\text { too ... so that it's not always to just chose the } \\
\text { actions and go according to that, but so that } \\
\text { there's a possibility that if you succeed to a } \\
\text { certain degree, there's a bonus. }\end{array}$ \\
\hline $\begin{array}{l}\text { Scheme/concept } \\
\text { positive, } \\
\text { implementation } \\
\text { sceptic }\end{array}$ & 2 & $\begin{array}{l}\text { If there are many different species and if each } \\
\text { requires management at a different time -if } \\
\text { there's a bit of this and a bit of that, would you } \\
\text { have to do management many times [a } \\
\text { season]? That would increase the workload. }\end{array}$ \\
\hline $\begin{array}{l}\text { Initially sceptical of } \\
\text { scheme, develops } \\
\text { to more positive }\end{array}$ & 1 & $\begin{array}{l}\text { This type of scheme with management thinking, } \\
\text { that you manage and watch that the species } \\
\text { thrive, it would be half way between buffer } \\
\text { zone [which requires removal of hayed } \\
\text { material] and NMG. That would appeal to } \\
\text { many. }\end{array}$ \\
\hline $\begin{array}{l}\text { Sceptical/hesitant } \\
\text { throughout }\end{array}$ & 3 & $\begin{array}{l}\text { [Management] has to be clearly stated, what } \\
\text { seed amount, the minimum and what type... } \\
\text { the spelled-out model. }\end{array}$ \\
\hline \multicolumn{3}{|c|}{ Comprehension of biodiversity as result in results-based approach framework } \\
\hline Immediate & 11 & $\begin{array}{l}\text { The idea is to get a good blooming meadow. } \\
\text { But first we have to think what that requires: it } \\
\text { requires the right soil type. And we have clay } \\
\text { soils, and in this village the NMG are near } \\
\text { forest edges, where saplings spring up quickly. }\end{array}$ \\
\hline Early & 5 & $\begin{array}{l}\text { Quite interesting, this. Compensation level } \\
\text { increases according to having more species in } \\
\text { the field. These are mainly natural species, so if } \\
\text { you don't have them then you have to be } \\
\text { satisfied with the basic level payment. }\end{array}$ \\
\hline Middle & 3 & $\begin{array}{l}\text { This wouldn't work for NMG established in the } \\
\text { past } 10 \text { years. They don't have these types of } \\
\text { plants. But those parcels - we have a few - that } \\
\text { have been fallow since the ' } 90 \text { s, some of these } \\
\text { species grow in the hay there. This could be for } \\
\text { those. }\end{array}$ \\
\hline Late & 1 & $\begin{array}{l}\text { In the case it's something on the side } \\
\text { somewhere, where it doesn't spread [weeds] so } \\
\text { much ... of course you get the biodiversity, but } \\
\text { what about other nature values? }\end{array}$ \\
\hline
\end{tabular}

occurrence of those species' (Farmer 10). Building on their existing outlets for accessing professional information, they suggested availability of materials online, a contact person in the advisory services, and voluntary on-site training or visits to model NMG sites as ways to build capacity for the scheme.

All farmers interviewed eventually understood the biodiversity enhancement aim of the hypothetical results-based approach for NMG. However, comprehension happened at different times during the interviews (Table 4). The four 'comprehension' categories are based on the farmers' indications of comprehension: immediate understanding, within the first quarter of discussion (early), after the first quarter but before the last quarter (middle), or in the last quarter of farm table discussion or in the field (late).

Farmhouse table discussions were framed by the two types of NMGs. Farmers discussed the practical challenges of achieving a 'nice blooming meadow' (Farmer 16) (Table 4) and many focused on what they need to do and what it will cost. Most deduced themselves that the indicator species would thrive on nutrient poor soils and would be more prevalent in old fallows and certain soil types. Still, farmers frequently discussed the scheme in terms of the short-term NMGs and focused on opportunity costs of sowing meadow species in the NMG. There are two likely reasons for farmers' emphasis on the short-term fallows. Firstly, those sites are more visible to the farmers in frequency of planning and actions undertaken. Secondlv. the assumption of the need to sow meadow species, as one would for the meadow field scheme, as well as statements from farmers who expressed scepticism of the approach (Table 4) are indicative of their experience and understanding of the actions-based AES approach: one must undertake an action in order to receive a payment.

\subsection{Result-based approach-enhancing or diluting good farmer ideal?}

Both intrinsic interest in nature management and motivation based on financial reward were evident in the interviews. The farmers pointed out that interest in the proposed results-based scheme would be entirely up to personal preference of the farmers, with those interested in pro-environment actions obviously keener to participate. In centive payment or a 'carrot' (Farmers 1, 5, 12 and 17) was mentioned as sufficient to raise interest for some but others, including farmers positive toward the scheme, asserted that actual costs must be covered by the bonus.

Farmers did not find 'counting flowers', a prerequisite for assessing the biodiversity value for a bonus payment, threatening to their identity as farmers or embarrassing in the eyes of peers. Peer and societal pressure was based on views of weeds and tidiness, and the few who said they did not mind the 'untidiness' of the NMG acknowledged that peers may judge them for it. Peer pressure was evident in farmers expressing that it is not always possible as a bystander to tell the difference between a neglected or managed field when it comes to NMG, which gives rise to concerns about what the fields signal to neighbours and peers about the particular farmer. It is viewed as affecting farmers' standing within the community: ' ... that I would put in something ... that would look like weeds when you look from afar, that would spread all kinds [of weeds], surely plenty of people would talk. They wouldn't come right out with it [to me], but they'd talk' (Farmer 4).

This passage captures a dual meaning mentioned by many farmers. Firstly, the farmer is worried about what others think about him/her and, secondly, part of being a good farmer is being a good neighbour and good member of society (Table 4). Thus, one should know better than to spread weeds to one's own or others' fields.

A recurring suggestion was to have a sign to inform people that the field is under a special biodiversity management. Such signs could be produced for the farmers. This response alternately aimed at increasing social capital to society at large by informing of the stewardship work the individual farmer or farmers-at-large do and, secondly, avoiding loss of social capital amongst peers.

\section{Discussion}

The study supports the notion that making nature more visible to farmers creates appreciation for biodiversity outcomes. The approach of 'producing biodiversity' suits the good farming ideal of a productive farm.

The perception of the farm to others if the NMG does not look good was the main drawback from a social capital point of view, but farmers also saw an opportunity to gain social capital through informing society and peers of the nature value of the NMG enrolled in the resultsbased bonus scheme. These findings are in line with the cultural scripts of good farm management and the importance of social capital (Vanclay et al., 2007; Burton, 2012).

\subsection{Good farming and managing for nature values}

Overall, managing for nature values fits with the good farming ideal. The elements of the hypothetical results-based scheme the farmers were most attracted to were the positive reinforcement of the payment for result and the idea of doing something good for nature. The 
farmers said that there is space for non-production elements on their farms and that NMG fits into their conceptualisations of good farming.

We found interest in the results-based approach generally and enthusiasm at finding biodiversity results during the field visits, where farmers were better able to conceive of biodiversity as an outcome. Nature observations and activities were shown to have personal meanings creating connections with farm history and prior generations and for providing context for social activities. These findings suggest farmers could also learn appreciation of biodiversity outcomes in NMG and operationalize the results-based approach in practice, as the self-monitoring would create new ways of observing and documenting the farm's nature.

The results show a greater acceptance of non-productivist values than that indicated for Finland by Silvasti (2003), which is possibly explained by the mainstreaming of the multifunctional agriculture approach through the AES, but may also be affected by the topic of the interviews. However, farmers clearly did not want the proposed resultsbased scheme's payment to be so attractive that it would result in good arable land being taken out of production. Rather, the scheme fits notions of good farming as long as it remains as a tool for marginal farmland. The finding is consistent with the cultural scripts of farming and good farming described by Vanclay et al. (2007) and by Burton and others and is in line with Hodge and Reader's (2010) findings from the UK of pragmatism being the main reason for participation in entrylevel environmental schemes. In this case, the focus on marginal farmland is suitable, as marginal lands with poor soils are the most likely to meet criteria for inclusion in the proposed results-based scheme.

The common presence of voluntary non-subsidised activities beneficial for nature and observations is positive for the implementation of the results-based approach for biodiversity conservation because it shows a ready interest for promotion of at least some types of biodiversity. Our findings that farmers seemed to forget or dismiss their own non-subsidised nature activities show that farmers largely have a predisposition to nature observation and activities, even if they do not find these activities particularly noteworthy. This is in line with Lokhorst et al. (2010, 2011) and Van Dijk et al. (2016) on the differences between farmers' subsidised and non-subsidised activities. The results-based approach, accompanied by suitable advisory support, would help farmers see their own activities in a new light as the ecological results become visible to the farmer through the eyes of others. This could, in turn, strengthen the view of nature management as part of good farming and build social capital (cf. Magda et al., 2015).

The contrast of lack of visibility of nature in NMG with the high visibility of nature in the game management fields may relate to game field having a clear aim. Management for promoting game is an understandable target and so a special effort is made in some cases. NMG, on the other hand, has no special target and is instead defined broadly as being "for biodiversity", which may be too vague and obscure a definition for farmers to find useful. Rather, the farmers seem to need concrete associations: e.g. game, pollinators, nice flowers, or well known bird species ( $c f$. Herzon and Mikk). The finding echoes that of a study of two schemes in England, which found that the scheme focused on positive enhancement had greater impact on participants' awareness of wildlife and other nature compared to the scheme focused on maintenance (Wilson and Hart, 2001). Emphasis on game species and birds over less visible biodiversity is in line with Herzon and Mikk (2007) and Soini and Aakkula (2007).

\subsection{Operationalizing ecological results and rewards}

Farmers expressed interest in the hypothetical results-based scheme and interest grew in the field where biodiversity results were more visible. The results are in line with findings that learning about biodiver-
(Gerowitt et al., 2003; Klimek et al., 2008; Magda et al., 2015) but also with findings that farmers hope for target species without further activities (Haaren and Bathke, 2008).

The importance of trusted and accessible advisory services for success in AES is well documented (e.g. Allen et al., 2014; Schroeder et al., 2015; Riley, 2016), including from Finland (Seppänen and Helenius, 2004; Birge and Herzon, 2014). The interesting result for advisory services in this study is the extent to which farmers expressed interest for guidance on best practices for achieving result and suggested ways to disseminate information to the farmers through the trainings they already attend and through demonstration, online materials, and extension agents.

That the farmers see good farming as legitimately improving the farm through good agronomic practices and taking farming seriously is positive for implementing the results-based approach because it requires farmers' engagement and interest for producing result (Fleury et al., 2015; Russi et al., 2016). In this regard, the approach encourages good farming. The study cannot, however, address cultural sustainability of the results-based approach in the face of competing land use options, such as seen in Germany where the result-based payment for extensive grassland (MEKA-B4) attracted only farmers who had structural and other conditions that made the results-based payment attractive to them because the payment was significantly too low to cover the opportunity costs of intensive farmers and biogas producers (Russi et al., 2016).

The classification of farmers that we developed (Table 2) largely corresponds to the 'conservation vs. economic', 'alternative vs. conventional', and 'stewardship vs. productivism' orientations prevalent in the literature and described by Maybery et al. (2005) and Huttunen and Peltomaa (2016). Maybery et al. (2005) assert that classification of farmers according to conservation and economic conceptualisations can aid in landholder goal-targeting to induce land stewardship behaviours. Following Russi et al. (2016) and Matzdorf and Lorenz (2010), who found that the farmers who participated in a results-based scheme in Germany already had positive attitudes toward nature conservation prior to enrolment in the scheme, we hypothesize that the first two categories of farmers in our study ('nature values highly central'; 'nature values well integrated, with clear multifunctional thinking, strategies and knowledge') are the most likely for uptake of the proposed resultsbased scheme according to their predisposition for environmental activities. With proper advisory support, the potential of the third category for positive change is high, as the group is interested in the approach but largely lacks knowledge and experience for carrying out activities for environmental outcomes. The last category is unlikely to be predisposed toward 'counting flowers', although they could become interested in the scheme if implementation is seen as successful, they have sites that easily meet the indicator species requirements, and the payment sum offsets any opportunity costs (Russi et al., 2016).

The proposed results-based scheme may also be attractive to farmers interested in innovation, as we saw in some of the interviews, and those who derive personal satisfaction through increased freedom, observation, or improved management outcome, as mentioned by two farmers.

\subsection{Building on the good farmer ideal}

The two areas where the results-based approach can enhance the good farmer ideal is through strengthening integration of nature values in farming and through potentially generating social capital through farmland nature management.

Though 'counting flowers' did not threaten farmer identity, normative aspects of 'good farming' affecting NMG manifested as peer pressure, with the potential loss of social capital through the act or even the 
new norms is necessary for the policy to take root if unreasonable social cost to early adopters is to be avoided. It also illustrates the need for an overall improved understanding and acceptance of field-level biodiversity among farmers (Herzon and Mikk, 2007).

The field walks showed there is opportunity to show farmers that active management that promotes the indicator plant species can improve the visual and ecological quality while also making unproductive corners of the farm productive through intentional biodiversity cultivation. Since only very few species are difficult agronomic weeds, the management could be flexible and allow for their targeted control. As these plants are often also dominants that outcompete most other species, their control is a win-win.

\section{Conclusion}

We examined potential cultural acceptability of the results-based approach in Finland using a hypothetical bonus element for an existing scheme with high variability of biodiversity value. Our results show that a hypothetical results-based AES with the central concept of 'managing for biodiversity outcomes' can fit with farmers' views of good farming and that farmers can operationalize ecological results for which they would be rewarded. Our results provide evidence for potential cultural acceptability for an AES payment approach currently absent from Finland and many other EU countries. The results suggest an opportunity and challenge for the existing AES structure in Finland, as well as elsewhere in the $\mathrm{EU}$, to become more proactive in trying to achieve biodiversity results in farmland through working with, and rewarding farmers for, producing measurable outcomes instead of simply fulfilling a set of obligations in return for payment.

The study adds its own contribution, visibility of nature to farmers, to develop analysis of how and why the physical and ecological, social, and the personal social relations should be taken into account for creating culturally acceptable AES. The results-based approach relies on 'visibility of nature' for the self-monitoring and appreciation of the outcome aims, as well as for adaptive management and, of course, for payment.

The process of presenting and discussing the proposed results-based scheme showed a capacity among the interviewed farmers for engagement with the results-based approach as a concept and ability to consider the approach both from the personal own farm perspective, as well as how it applies generallyto Finnish agriculture. Increased autonomy and identifying nature results as a production outcome builds on the existing 'good farmer' ideal.

The 'tidy farm' is one cultural script and part of the 'good farming' ideal. It permeates farm management, including management of nonproduction fields. These normative views present both challenges and opportunities: social capital is at risk if farmland elements are perceived as unmanaged and if the biodiversity value of the elements are under-appreciated by farmers and secondary to the tidy farm ideal. However, these risks could potentially be mitigated through a resultsbased scheme with appropriate advisory services, which could raise the profile of non-production fields and areas for biodiversity by giving the more valuable sites a 'production' status via measurable biodiversity outcome. Crucially, policy can build on and develop the meaning of good farming and elements that form cultural scripts, but it cannot bypass them if the aim is to create lasting change.

\section{Acknowledgements}

We thank all the participants in the study and acknowledge funding of Emil Aaltonen Foundation and the University of Helsinki. We also thank Minna Kaljonen for valuable input. The authors also thank Tobias Plienenger and Lee-Ann Sutherland and three anonymous review-

\section{Appendices.}

Table A.1

Current reasons for having nature management grassland, according to the farmers. 'Con venience/best subsidy format' describes mainly long-term fallows and also refer in some cases to sites that have acceptable agronomic qualities but are far away. 'Agronomic' refers to sites that are part of the farmers' crop rotation.

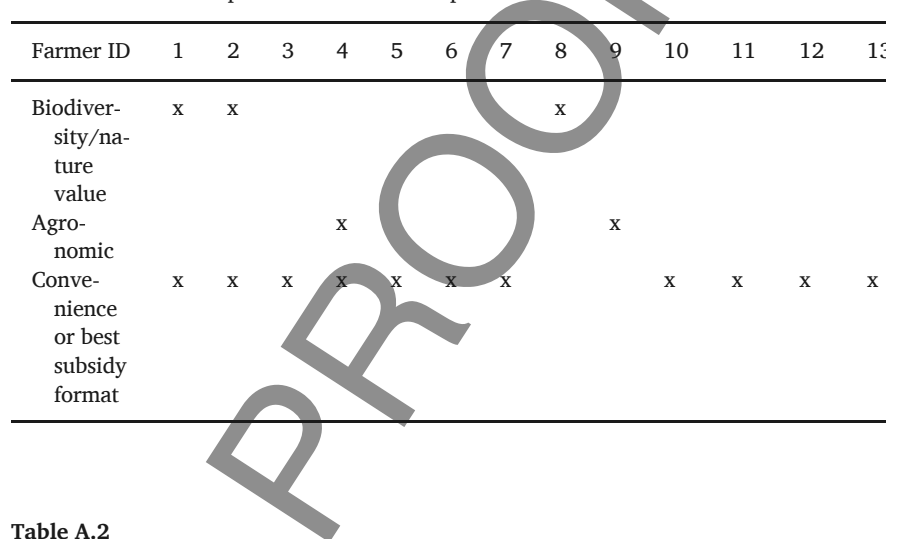

Table A.2

Farmer-specific results for attitude toward scheme and the comprehension score for bio diversity result. 'Comprehension' refers to at what stage of the interview the farmer grasped that producing biodiversity is the target outcome.

\begin{tabular}{lll}
\hline Farmer & $\begin{array}{l}\text { Attitude toward scheme \& } \\
\text { concept }\end{array}$ & $\begin{array}{l}\text { Comprehension of biodiversity as re- } \\
\text { sult in results-based framework }\end{array}$ \\
\hline 1 & $\begin{array}{l}\text { Positive throughout } \\
\text { Positive throughout } \\
\text { Positive throughout }\end{array}$ & $\begin{array}{l}\text { Immediate } \\
\text { Middle }\end{array}$ \\
4 & Sceptical/hesitant throughout & Middle \\
5 & Positive throughout & Early \\
6 & Positive throughout & Early \\
7 & Positive throughout & Early \\
8 & Positive throughout & Immediate \\
9 & Positive throughout & Immediate \\
10 & Positive throughout & Immediate \\
11 & Positive throughout & Early \\
12 & Positive throughout & Immediate \\
13 & Scheme/concept positive, im- & Immediate \\
& plementation sceptic & \\
14 & Initially sceptical of scheme, & Immediate \\
& develops to more positive & \\
15 & Sceptical/hesitant throughout & Early \\
16 & Scheme/concept positive, im- & Immediate \\
& plementation sceptic & \\
17 & Positive throughout & Immediate \\
18 & Sceptical/hesitant throughout & Middle \\
19 & Positive throughout & Immediate \\
20 & Positive throughout & Immediate \\
\hline & &
\end{tabular}

Table A.3

Quotes indicating farmer comprehension of scheme's biodiversity aims. Comprehension of biodiversity aims were inferred from statements such as these - farmers were not asked directly whether they understood the biodiversity aim.

\begin{tabular}{ll}
\hline $\begin{array}{l}\text { Farmer } \\
\text { ID }\end{array}$ & Comprehension of biodiversity aims \\
\hline 1 & $\begin{array}{l}\text { It sounds interesting; that there's always a field or meadow that is species-rich. } \\
\text { That way maybe there would be more butterflies, more small insects. It would } \\
\text { be more diverse. }\end{array}$ \\
& $\begin{array}{l}\text { It doesn't sound very arduous ... the [indicator] species should be some that } \\
\text { suit together and to the soil type. If they have to be sown they must also pro- } \\
\text { duce a result. }\end{array}$ \\
& $\begin{array}{l}\text { Well, of course if one aims for the result to be better for nature, then that's ok. } \\
\text { That's part of the current system. } \\
\text { In the case it's something on the side somewhere, where it doesn't spread } \\
\text { [weeds] so much ... of course you get the biodiversity, but what about other }\end{array}$
\end{tabular}


$5 \quad$ It would be good to get this type of scheme that has a little carrot, that there would be more biodiversity in the field, that would be good. Because I am afraid that the current NMGs generally may be quite uniform.

6 Now when you've heard how I do things, you can see I am quick to grab this kind of thing. Otherwise I would be growing oat and wheat and malt barley as before. But I've turned toward this nature side.

$7 \quad$ Quite interesting, this. Compensation level increases according to having more species in the field. These are mainly natural species, so if you don't have them then you have to be satisfied with the basic level payment.

$8 \quad 50-100 €$ surely is enough to get people going and at the same time follow with observation of their own sites.

9 About 10 species is a good amount. If I had to choose [indicator species], I'd say wild strawberry. Corn flower - we've had them sometimes.

I could be interested ... I don't have a view on the indicator species. I've seen there's more there than just hay [species], but [I don't know]. If the aim is to have an incentive idea, this works; that the more you naturally have places where these species thrive then, yes, you'll want to do better there. Self-monitoring could be once a year instead of every second year. Because the idea is not just to go there, but also to find the species. And if there would be some kind of payment incentive for grazing, then a smaller payment would be ok

If [the indicator plants] are there, then something has been done that they are there. But it is the NMG fallow type that has advanced it. If it were in normal farming, they wouldn't be there. There'd be only weeds.

I have clay soils, they are nutrient rich. They aren't dry silty soils where such species are found in nature ... In theory, if the soil is in good condition, if it's clay and the hay is collected, then the sweet pea and vetches will grow, because that's where they belong ... but if clay soil is in good shape, these flowering meadow species don't thrive there.

15 NMG doesn't have weeds, per se. I am able to see it as enriching.

16 The idea is to get a good blooming meadow. But first we have to think what that requires: it requires the right soil type. And we have clay soils, and in this village the NMG are near forest edges, where saplings spring up quickly. Yes, I think these can be found from the old fields. This wouldn't work for NMG established in the past 10 years. They don't have these types of plants. But those parcels - we have a few - that have been fallow since the '90s, some of these species grow in the hay there. This could be for those. Normally NMG is mainly grass and the flora quite monotonous. So in those kinds of fields I don't think 10 different species would be found. It's good that there would be more compensation, but also good that biodiversity would increase.

\section{References}

Ahnström, J., 2009. Farmland Biodiversity - in the Hands and Mind toral thesis Swedish University of Agricultural Sciences, Uppsala

Ahnström, J., Höckert, J., Bergeå, H.L., Francis, C.A., Skelton, P., Hallgren, L., 2008. Farmers and nature conservation: what is known about attitudes, context factors and actions affecting conservation?. Renew. Agric. Food Syst. 24 (1), 38-47.

Allen, B., Hart, K., Radley, G., Tucker, G., Keenleyside, C., Oppermann, R., Underwood, E., Menadue, H., Poux, X., Beaufoy, G., Herzon, I., Povellato, A., Vanni, F., Pražan, J., Hudson, T., Yellachich, N., 2014. Biodiversity Protection through Results Based Remuneration of Ecological Achievement. Report Prepared for the European Commission, DG Environment Institute for European Environmental Policy, London, 167 pp.

[Computer software] ATLAS.ti Software Version 4.2, 1999. Scientific Software Development, Berlin.

Batáry, P., Dicks, L.V., Kleijn, D., Sutherland, W.J., 2015. The role of agri-environment schemes in conservation and environmental management. Conserv. Biol. 29 (4), 1006-1016.

Bergeå, H.L., Martin, C., Sahlström, F., 2008. "I don't know what you're looking for": professional vision in Swedish agricultural extension on nature conservation management. J. Agr. Educ. Ext. 1 (4), 329-34

Birge, T., Herzon, I., 2014. Farmer and landowner motiyations and experiences in managing rare semi-natural biotopes: a case from Finland. Land Use Pol. 41, 128-137. https://doi.org/10.1016/j.landusepol.2014.05.004.

Birge, T., Toivonen, M., Kaljonen, M., Herzon, H., 2017. Probing the Grounds: developing a payment-by-results agri-environment scheme in Finland. Land Use Pol. 61, 302315.

Bourdieu, P., 1984. Distinction. A social critique of the judgement of taste. Translated by R. Nice. Routledge, London. Cited in Sutherland, L.A., Darnhofer, I. 2012 J. Rural Stud. 28, 232-240.

Bourdieu, P., 1986. The forms of capital. In: Richardson, J. (Ed.), Handbook of Theory and Research for the Sociology of Education. Greenwood Press, New York, pp. 4658.

Burgess, J., Clark, J., Harrison, C.M., 2000. The values of wetlands: landscape and institutional perspectives. Ecol. Econ. 35, 119-132.

Burton, R.J.F., 2004. Seeing through the 'good farmer's' eyes: towards developing an understanding of the social symbolic value of 'productivist' behaviour. Sociol. Rural.
Burton, R.J.F., 2012. Understanding farmers' aesthetic preference for tidy agricultural landscapes: a bourdieusian perspective. Landsc. Res. 37 (1), 51-71.

Burton, R.J.F., Kuczera, C., Schwarz, G., 2008. Exploring farmers' cultural resistance to voluntary agri-environmental schemes. Sociol. Rural. 48 (1), 16-37.

Burton, R.J.F., Paragahawewa, U.H., 2011. Creating culturally sustainable agri-environmental schemes. J. Rural Stud. 27, 95-104.

Burton, R.J.F., Schwarz, G., 2013. Result-oriented agri-enyironmental schemes in Europe and their potential for promoting behavioural change. Land Use Pol. 30, 628-641.

de Krom, M.P.M.M., 2017. Farmer participation in agri-environmental schemes: regionalisation and the role of bridging social capital. Land Use Pol. 60, 352-361.

de Snoo, G.R., Herzon, I., Staats, H., Burton, Rob J.F., Schindler, S., van Dijk, J., Lokhorst, A.M., Bullock, J., Lobley, M., Wrbka, T., Schwarz, G., Musters, C.J.M., 2013. Towards effective nature conservation on farmland: making farmers matter. Conserv. Lett. 6, 66-72.

European Environment Agency, 2004. High Nature Value Farmland: Characteristics, Trends and Policy Challenges, Copenhagen. 31 pp http://www.eea.europa.eu/ publications/report_2004_1Accessed 15 December 2015.

European Network for Rural Development and European Commission, 2010. Report on the Contribution of the European Network for Rural Development to the Public Debate on the Common Agricultural Policy After 2013 (13/07/2010). European Commission, Brussels http://enrd.ec.europa.eu/enrd-static/fms/pdf/DAB81B97-9E9BF50F-6F18-C76EBF6B1A4A.pdfAccessed 24 June 2011.

European Court of Auditors, 2011. Is Agri-Environment Support Well Designed and Managed?. Special report no. 7/2011 European Union, Luxembourg, 75 pp http://eca. europa.eu/portal/pls/portal/docs/1/8772726.PDFAccessed 15 December 2015.

Fleury, P., Seres, C., Dobremez, L., Nettier, B., Pauthenet, Y., 2015. "Flowering Mead ows", a result-oriented agri-environmental measure: technical and value changes in favour of biodiversity. Land Use Pol. 46, 103-114.

Gerowitt, B., Isselstein, J., Marggraf, R., 2003. Rewards for ecological goods - requirements and perspectives for agricultural land use. Agr. Ecosyst. Environ. 98, 541-547.

Gibson, W.J., Brown, A., 2009. Working with Qualitative Data. SAGE online resource, 222pp http://methods.sagepub.com/book/working-with-qualitative-dataAccessed 10 January 2017.

Haaren, C., Bathke, M., 2008. Integrated landscape planning and remuneration of agrienvironmental services- results of a case study in the Fuhrberg region of Germany. J. Environ. Manag. 89, 209-221.

Helenius, J., Seppänen, L., 2004. Do inspection practices in organic agriculture serve organic values? A case study from Finland. Agric. Hum. Val. 21, 1-13.

Herzon, I., Mikk, M., 2007. Farmers' perceptions of biodiversity and their willingness to enhance it through agri-environment schemes: a comparative study from Estonia and Finland. J. Nat. Conserv. 15, 10-25.

Herzon, I., Birge, T., Allen, B., Povellato, A., Vanni, F., Hart, K., Radley, G., Tucker, G., Keenleyside, C., Oppermann, R., Underwood, E., Menadue, H., Poux, X., Beaufoy, G., Pražan, J., Hudson, T., Yellachich, N., 2018. Time to look for evidence: results-based approach to conservation on farmland in Europe. Land Use Pol. 71, 347-354.

Hodge, I., 2001. Beyond agri-environmental policy: towards an alternative model of rural environmental governance. Land Use Pol. 18, 99-111.

dge, I., Reader, M., 2010. The introduction of entry level stewardship in England: extension or dilution in agri-environment policy?. Land Use Pol. 27, 270-282.

Huttunen, S., Peltomaa, J., 2016. Agri-environmental policies and 'good farming' in cultivation practices at Finnish farms. J. Rural Stud. 44, 217-226.

Kaljonen, M., 2006. Co-construction of agency and environmental management. The case of agri-environmental policy implementation at the Finnish farms. J. Rural Stud. 22, 205-216.

Kaljonen, M., 2008. Bringing back the lost biotopes. The practice of regional biodiversity management planning in Finland. J. Environ. Plann. Man. 10, 113-132.

Keenleyside, C., Allen, B., Hart, K., Menadue, H., Stefanova, V., Prazan, J., Herzon, I., Clement, T., Povellato, A., Maciejczak, M., Boatman, N., 2011. Delivering Environmental Benefits through Entry Level Agri-Environment Schemes in theEU. Report Prepared for DG Environment Institute for EuropeanEnvironmental Policy, London.

Klimek, S., Richter gen. Kemmermann, A., Steinmann, H.-H., Freese, J., Isselstein, J., 2008. Rewarding farmers for delivering vascular plant diversity in managed grasslands: a transdisciplinary case-study approach. Biol. Conserv. 141, 2888-2897.

Little, J., 2002. Rural geography: rural gender identity and the performance of masculin ity and femininity in the countryside. Prog. Hum. Geogr. 26 (5), 665-670.

Lokhorst, A.M., Staats, H., van Dijk, J., van Dijk, E., de Snoo, G., 2010. Using tailored information and public commitment to improve the environmental quality of farm lands: an example from The Netherlands. Hum. Ecol. 38, 113-122.

Lokhorst, A.M., Staats, H., van Dijk, J., van Dijk, E., de Snoo, G., 2011. What's in it for me? Motivational differences between farmers' subsidized and non-subsidised conservation practices. Appl. Psychol. 60, 337-353.

Magda, D., de St. Marie, C., Plantureux, S., Agreil, C., Amioud, B., Mestelan, P., Mihout, S., 2015. Integrating agricultural and ecological goals into the management of species-rich grasslands: learning from the flowering meadows competition in France. Environ. Manag. 56, 1053-1064.

Matzdorf, B., Kaiser, T., Rohner, M.-S., 2008. Developing biodiversity indicators to design efficient agri-environmental schemes for extensively used grassland. Ecol. Indic. 8, 256-269.

Matzdorf, B., Lorenz, J., 2010. How cost-effective are result-oriented agri-environmental measures? An empirical analysis in Germany. Land Use Pol. 27, 535-544.

Maybery, D., Crase, L., Gullifer, C., 2005. Categorising farming values as economic, conservation and lifestyle. J. Econ. Psych. 26, 59-72.

MAVI, 2018. Peltovalvontaohje 2018. Asianro. 97/03.00.01/2018. In: www.mavi.fi/fi/ oppaat-ja-lomakkeet/viljelija/Sivut/valvonnan-oppaat.aspx, Accessed 13 February 2017.

Natural Resources Institute Finland 2016. https://portal.mtt.fi/portal/page/portal/ economydoctor/structural_development/2015/ely_centers [accessed 13.2.2017].

Paulus, T.M., Lester, J.N., 2016. ATLAS.ti for conversation and discourse analysis studies. 
Pe'er, G., Lakner, S., Müller, R., Passoni, G., Bontzorlos, V., Clough, D., Moreira, F., Azam, C., Berger, J., Bezak, P., Bonn, A., Hansjürgens, B., Hartmann, L., Kleemann, J., Lomba, A., Sahrbacher, A., Schindler, S., Schleyer, C., Schmidt, J., Schüler, S., Sirami, C., von Meyer-Höfer, M., Zinngrebe, Y., 2017. Is the CAP Fit for Purpose? an Evidence Based Fitness-Check Assessment. German Centre for Integrative Biodiversity Research (iDiv) Halle-Jena-Leipzig, Leipzig.

Poláková, J., Tucker, G., Hart, K., Dwyer, J., Rayment, M., 2011. Addressing Biodiversity and Habitat Preservation through Measures Applied under the Common Agricultural Policy. Report Prepared for DG Agriculture and Rural Development, Contract No. 30CE-0388497/00-44 Institute for European Environmental Policy, London.

Pullin, A.S., Knight, T.M., 2003. Support for decision making in conservation practice: an evidence-based approach. J. Nat. Conserv. 11, 83-90.

Riley, M., 2014. Still being a 'good farmer': (non-)retirement and the preservation of farming identities in older age. Sociol. Rural. 56 (1), 97-115.

Riley, M., 2016. How does longer term participation in agri-environment schemes [re]shape farmers' environmental dispositions and identities?. Land Use Pol. 52, 6275.

Russi, D., Margue, H., Oppermann, R., Keenleyside, C., 2016. Result-based agri-environment measures: market-based instruments, incentives or rewards? The case of Baden Württemberg. Land Use Pol. 54, 69-77.

Ryan, G.W., Bernard, H.R., 2003. Techniques to identify themes. Field Methods 15, 85109.

Saunders, F.P., 2016. Complex shades of green: gradually changing notions of the 'good farmer' in a Swedish context. Sociol. Rural. 56 (3), 391-407.

Schneider, F., Ledermann, T., Fry, P., Rist, S., 2010. Soil conservation in Swiss agriculture -approaching abstract and symbolic meanings in farmers' life-worlds. Land Use Pol. 27, 332-339.
Silvasti, T., 2003a. Bending borders of gendered labour division on farms. Sociol. Rural. 43 (2), 154-166.

Silvasti, T., 2003b. The cultural model of "the good farmer" and the environmental question in Finland. Agr. Hum. Values 20, 143-150.

Soini, K., Aakkula, J., 2007. Framing the biodiversity of agricultural landscape: the essence of local conceptions and constructions. Land Use Pol. 24, 311-321.

Sutherland, L.A., Burton, R.J.F., 2011. Good farmers, good neighbours? The role of social capital in social capital development in a Scottish farming community. Sociol. Rural. 51 (3), 238-255.

Sutherland, L.A., Darnhofer, I., 2012. Of organic farmers and 'good farmers': changing habitus in rural England. J. Rural Stud. 28, 232-240.

Toivonen, M., Herzon, I., Helenius, J., 2013. Environmental Fallows as a new policy tool to safeguard farmland biodiversity in Finland. Biol. Conserv. 159, 355-366.

Toivonen, M., Herzon, I., Kuussaari, M., 2015. Differing effects of fallow type and landscape structure on the occurrence of plants, pollinators and birds on environmental fallows in Finland. Biol. Conserv. 181, 36-43.

Uthes, S., Matzdorf, B., 2013. Studies on agri-environmental measures: a survey of the literature. Environ. Manage. 51 (1), 251-266.

Vanclay, F., Enticott, G., 2011. The role and functioning of cultural scripts in farming and agriculture. Sociol. Rural. 51 (3), 256-271.

Vanclay, F., Silvasti, T., Howden, P., 2007. Styles, parables and scripts: diversity and conformity in Australian and Finnish Agriculture. Rural Soc. 17 (1), 3-8.

Van Dijk, W.F.A., Lokhorst, A.M., Berendse, F., de Snoo, G.R., 2016. Factors underlying farmers' intentions to perform unsubsidised agri-environmental measures. Land Use Pol. 59, 207-2016.

Wilson, G.A., Hart, K., 2001. Farmer participation in agri-environmental schemes: towards conservation-oriented thinking?. Sociol. Rural. 41 (2), 254-274.

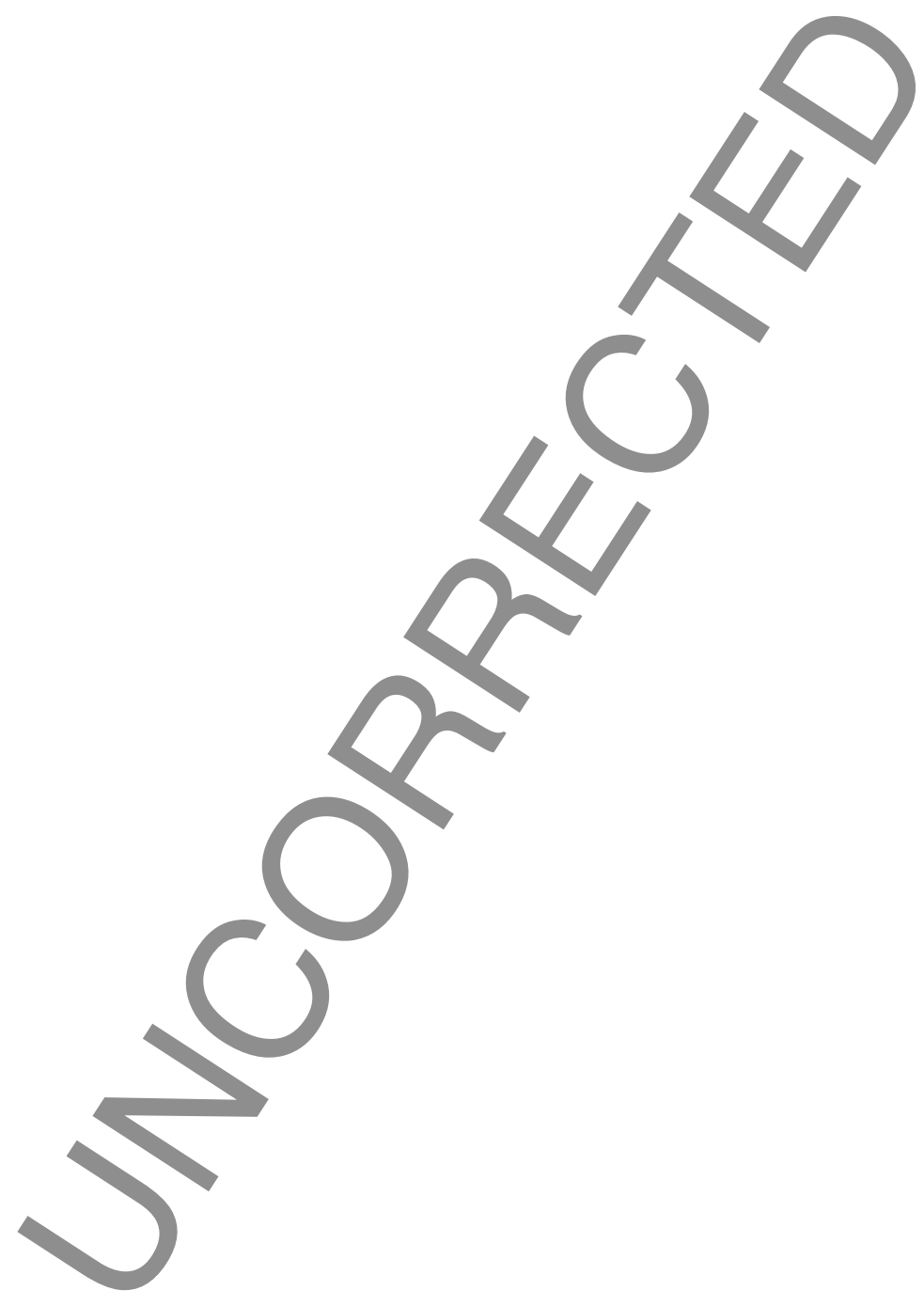

